\title{
PENGARUH EARNINGS MANAGEMENT TERHADAP KINERJA
}

\author{
Aida Ainul Mardiyah \\ STIE Malangkuçeçwara Malang
}

\begin{abstract}
This research is aimed at giving empirical evidence that earning management does influence performance. The 153 sample from 1997 to 2001 is determined by using stratified random sampling. Multiple regression analysis is used to test hypotheses based on this archival data.

The result of the analysis shows that earning management influences performance. This is in line with Barnea et al. (1976), Mones (1987), Ilmainir (1993), Hapworth (1953) in Ashari et al. (1994), Arhibald (1967) in Ashari et al. (1994), Ashari et al. (1994: 292), Zuhroh (1996), Jin (1997), Godfrey and Jones (1999), Defond and Jiambalvo (1994) in Scott (2000), Sweeney (1994) in Scott (2000), Ghofar (2001), Tarjo (2002), and Mardiyah (2003) which also conlude that earning management influences performance.
\end{abstract}

Keywords: earnings management, performance, stratified random sampling.

\section{PENDAHULUAN}

Earnings management ini akan mengakibatkan penurunan kinerja (underperformance) setelah penawaran (McLaughlin et al., 1996; Alderson dan Betker, 1997; Loughran dan Ritter, 1997; Teoh et al., 1998; Rangan, 1998; serta Trail dan Vos, 2001). Ada berbagai motivasi yang mendorong dilakukannya earnings management yaitu motivasi bonus (bonus purposes), motivasi kontrak (contractual motivations), motivasi politik (political motivations), motivasi pajak (taxes motivations), perubahan chief executive officers (changes of CEO), IPO dan mengkomunikasikan informasi ke investor (to communicate information to investors) (Scott, 2000). Lebih lanjut, motivasi-motivasi tersebut dapat dikategorikan menjadi kelompok: 1) penilaian dan harapan pasar modal; 2) kontraktual; dan 3) anti-trust atau regulasi pemerintah lainnya (Healy dan Wahlen, 1998; serta Sulistyanto dan Midiastuti, 2002).

Motivasi pasar modal berkaitan dengan earnings management. Alasan earnings management, misalnya management buyout (Perry dan William, 1994), initial public offerings (Teoh et al., 1997, 1998; dan DuCharme et al., 2000), seasoned equity offerings (Teoh et al., 1998; dan Rangan, 1998). Walaupun perusahaan sudah melakukan earnings management, investor tersebut tidak naif dan investor juga masih mempertimbangkan informasi aliran kas (cash flow) (Teoh et al., 1997; serta Healy dan Wahlen, 1998). Hal ini disebabkan laba mampu memprediksi aliran kas masa depan lebih baik daripada aliran kas (Dechow et al., 1995).

Motivasi kontrak muncul karena perjanjian antara manajer dan perusahaan yang berbasis pada kompensasi manajerial (managerial compensation) dan perjanjian utang (debt convenant). Motivasi bonus merupakan dorongan bagi manajer perusahaan dalam melaporkan laba yang diperolehnya untuk memperoleh bonus yang dihitung atas dasar laba tersebut. Jika laba lebih rendah daripada target yang ditetapkan maka akan mendorong manajer untuk melakukan earnings management dengan mentransfer laba masa depan (future earnings) menjadi laba sekarang (current earnings) dengan harapan akan memperoleh bonus (Scott, 2000). Earnings management dilakukan oleh manajer dengan menggunakan discretionary accruals.

Motivasi regulasi (politik) merupakan motivasi yang muncul karena manajemen memanfaatkan kelemahan akuntansi yang menggunakan estimasi akrual dan pemilihan metoda 
akuntansi dalam mensiasati berbagai regulasi pemerintah. Perusahaan yang terbukti menjalankan praktik pelanggaran terhadap regulasi anti-trust dan anti monopoli, manajernya melakukan earnings management dengan menggunakan akrual untuk menurunkan laba yang dilaporkannya (Cahan, 1992; Na'im dan Hartono, 1996; serta Hartono dan Na'im, 1998). Perusahaan juga akan menggunakan discretionary accruals untuk menurunkan laba dengan tujuan untuk mempengaruhi keputusan pengadilan dalam menetapkan finalti terhadap perusahaan yang mengalami damage award (Hall dan Stammerjohan, 1997). Income taxation juga merupakan motivasi dalam earnings management (Setiawati, 2001). Pemilihan metoda akuntansi dalam pelaporan laba akan memberikan hasil yang berbeda terhadap laba yang dilaporkan yang dipakai sebagai dasar perhitungan pajak. Sehingga manajer cenderung untuk menggunakan metoda akuntansi yang menghasilkan laporan laba dan pajak yang relatif lebih rendah, misalkan memilih menggunakan metoda pencatatan persediaan LIFO (last in first out) daripada FIFO (first in first out) pada saat harga-harga naik. Karena dengan menggunakan LIFO laba dikendalikan menjadi lebih rendah dan akan menaikkan aliran kas, sedangkan apabila menggunakan FIFO akan berakibat pada biaya pajak yang lebih tinggi dan aliran kas yang lebih rendah (Scott, 2000).

Manajer cenderung lebih memilih kebijakan earnings management dengan mengendalikan transaksi akrual, yaitu transaksi yang tidak mempengaruhi aliran kas (Friedlan, 1994). Sementara di sisi lain, investor juga cenderung memusatkan perhatiannya pada laporan rugi-laba karena investor berpendapat bahwa kestabilan laba akan berdampak pada kestabilan deviden.

Transaksi akrual merupakan transaksi yang tidak mempengaruhi aliran kas masuk (cash inflow) maupun aliran kas keluar (cash outflow). Transaksi akrual bisa berwujud (Gumanti, 2000; serta Sulistyanto dan Midiastuti, 2002): 1) transaksi yang bersifat non-discretionary accruals, yaitu apabila transaksi telah dicatat dengan metoda tertentu maka manajemen diharapkan konsisten dengan metoda tersebut; dan 2) transaksi yang bersifat discretionary accruals, yaitu metoda yang memberikan kebebasan kepada manajemen untuk menentukan jumlah transaksi akrual secara fleksibel.

Asimetri informasi pada saat IPO mendorong manajemen melakukan earnings management sebelum dan sesudah penawaran (Teoh et al., 1997, 1998; Chambers, 1999; DuCharme et al., 2000; dan Beneish, 2001). Sikap oportunistik ini dilakukan manajemen dengan harapan investor memberi penilaian positif terhadap perusahaan dan merespon penawaran yang dilakukan perusahaan. Penerapan earnings management dengan income increasing dapat dilakukan dengan discretionary accruals maupun non discretionary accruals (McCulloch, 1998). Income increasing memang diijinkan regulasi akuntansi, dilakukan perusahaan dengan cara mengubah beberapa prinsip akuntansi melalui restatement yang berlaku surut dalam laporan keuangan yang ditunjukkan dalam prospectus penawaran (Teoh et al., 1997; Richardson, 1998; Chambers, 1999; dan DuCharme et al., 2000).

Penggunaan earnings management pada saat melakukan IPO melalui penaikan laba (income increasing). Penggunaan earnings management pada saat IPO dilakukan dengan menggeser pendapatan masa depan (future earnings) menjadi pendapatan sekarang (current earnings), sehingga laba pada perioda IPO akan dilaporkan lebih tinggi dari yang seharusnya. Sehingga meskipun dalam jangka pendek perusahaan mampu mempertahankan kinerja yang dilaporkan dengan lebih tinggi tersebut (overperformance), namun dalam jangka panjang penurunan kinerja tetap akan terjadi (Teoh et al., 1997, 1998; dan Espenlaub, 1999). Bahkan penurunan kinerja laba tersebut tetap terjadi meskipun terdapat pertumbuhan penjualan dan pengeluaran modal yang tinggi setelah IPO tersebut (Ritter, 1991 serta Jain dan Kini, 1994).

Teoh et al. (1997) serta Healy dan Wahlen (1998) menunjukkan bahwa 62\% perusahaan yang melakukan IPO melakukan earnings management. Dalam penelitian ini ditemukan bukti bahwa manajemen perusahaan yang melakukan IPO kemungkinan besar menaikkan labanya (income increasing) dengan menggunakan kebijakan depresiasi dan pengakuan kerugian piutang pada saat IPO dan beberapa tahun setelah IPO. Kebijakan tersebut bertujuan untuk menaikkan harapan 
investor terhadap kinerja perusahaan masa depan dan menaikkan harga penawaran (DuCharme et al., 2000). Hal ini didukung oleh Dechow et al. (1995) yang menunjukkan rata-rata harga saham akan menurun sekitar $9 \%$ ketika earnings management diumumkan.

Earnings management untuk meningkatkan kinerja dilakukan meningkatan laba (income increasing) menjelang penawaran, memuncak pada saat penawaran dan menurun setelah penawaran mengindikasikan sikap oportunistik manajemen untuk menaikkan harga saham yang ditawarkannya (McLaughlin et al., 1996; Alderson dan Betker, 1997; Teoh et al., 1998; serta Dubois dan Jeanneret, 2000). McLaughlin et al. (1996) dalam penelitiannya menggunakan berbagai ukuran rasio aliran kas untuk mengetahui apakah kinerja jangka panjang setelah SEO mengalami penurunan. Hasilnya mengindikasikan bahwa kinerja aliran kas mengalami penurunan sekitar 20\% selama tiga tahun setelah penawaran. Sementara Alderson dan Betker (1997) mengevaluasi kinerja operasi dan harga saham jangka panjang perusahaan yang melakukan SEO dengan menggunakan rasio market-to-book asset sebagai proksi nilai pertumbuhan oportunistik (value of growth opportunisties) dan menemukan bahwa kinerja operasi pasca penawaran dalam jangka panjang jelek.

Traill dan Vos (2001) melaporkan bahwa perusahaan yang melakukan SEO akan underperformance selama lima tahun. Penelitian Laughran dan Ritter (1997) menggunakan enam rasio keuangan untuk melihat kinerja keuangan sebelum dan lima tahun setelah SEO. Hasilnya menunjukkan rasio keuangan-khususnya rasio profit margin dan ROA-mengalami penurunan selama empat tahun setelah penawaran tersebut. Hasil tersebut mengindikasikan adanya upaya manajemen melakukan earnings management sebelum melakukan penawaran agar kinerja perusahaan pada saat penawaran kelihatan bagus. Penelitian yang dilakukan Teoh et al. (1998) melaporkan bahwa discreationary accruals digunakan oleh perusahaan yang melakukan SEO pada perioda sebelum issue, mencapai puncaknya pada saat issue, dan menurun pada perioda-perioda pasca issue. Selanjutnya penelitian tersebut membuktikan bahwa ada hubungan negatif antara discreationary current accruals sebelum issue dengan laba dan return saham pasca issue. Hubungan negatif dengan return saham ini terjadi setelah mengendalikan ukuran perusahaan, rasio book-tomarket, dan capital expenditures pasca issue.

Permasalahan keagenan ditelusuri dari beberapa kondisi, seperti earnings management (Defond dan Jiambalvo (1994) dalam Scott (2000); Sweeney (1994) dalam Scott (2000); Yurianto (2000); serta Mardiyah (2003)).

Berkaitan dengan hasil bukti empiris sebelumnya maka penelitian berusaha membuktikan pengaruh earnings management terhadap kinerja. Penelitian ini berbeda dari penelitian sebelumnya dalam beberapa hal yaitu:

1. Penelitian Mardiyah (2003) menguji secara komprehensif pengaruh struktur kepemilikan manajerial, earnings management, dan aliran kas bebas (free cash flow) terhadap utang dan kinerja perusahaan.

2. Penelitian menggunakan data panelan (pooled data) dengan alasan: a) variabel kontrol dengan menggunakan variabel kategoris (dummy) untuk menghindari bias data secara antara perusahaan (crossection) dan b) penelitian-penelitian di luar negeri untuk mengetahui indikasi earnings management data yang digunakan minimal 5 (lima) tahun sedangkan di Indonesia kurang dari lima tahun sehingga banyak penelitian di Indonesia hasilnya tidak konsisten

\section{TINJAUAN TEORI DAN PENGEMBANGAN HIPOTESIS}

\section{1. Teori Keagenan}

Jensen dan Meckling (1976) mendefinisikan hubungan keagenan sebagai sebuah kontrak dimana satu atau lebih prinsipal menyewa orang lain (agen) untuk melakukan beberapa jasa untuk kepentingan mereka dengan mendelegasikan beberapa wewenang untuk membuat keputusan kepada agen. Pemisahan kepemilikan dan pengendalian menyebabkan manajemen bertindak tidak 
sesuai dengan keinginan prinsipal. Dalam melaksanakan tugas manajerial, manajemen memiliki tujuan pribadi yang bersaing dengan tujuan prinsipal di dalam memaksimalkan kemakmuran pemegang saham. Pemisahan kepemilikan dan pengendalian perusahaan disebut konflik keagenan (agency conflict).

Jensen dan Meckling (1976) mengidentifikasi kos keagenan menjadi tiga kelompok, yaitu: 1) the monitoring expenditure by the principal adalah kos pengawasan yang harus dikeluarkan oleh pemilik; 2) the bonding cost adalah kos yang harus dikeluarkan akibat pemonitoran yang harus dikeluarkan prinsipal kepada agen; dan 3) the residual cost adalah pengorbanan akibat berkurangnya kemakmuran prinsipal karena perbedaan keputusan antara prinsipal dan agen.

\subsection{Pengaruh Earnings Management Terhadap Kinerja}

Perataan laba (income smoothing) sebenarnya merupakan salah satu hipotesis yang ada dalam earnings management. Income smoothing adalah usaha yang dilakukan manajer untuk mengelola laba sehingga sesuai dengan tujuan manajer. Praktik income smoothing dilakukan antara lain dengan cara memilih kebijakan akuntansi tertentu yang sesuai dengan kepentingan manajer atau merubah estmasi-estimasi akuntansi (Tarjo, 2002).

Income smoothing merupakan praktik di mana manajer memilih metoda atau kebijakan akuntansi tertentu sehingga varian atau fluktuasi earnings dapat diminimalkan. Dalam praktik ini, manajer akan berusaha menurunkan earnings ketika kinerja atau laba operasinya dianggap terlalu tinggi dan sebaliknya akan berusaha menaikkan earnings yang dilaporkan bila kinerja operasi perusahan dianggap terlalu rendah. Kinerja manajemen akan dianggap kurang baik jika earnings perusahaan bersifat fluktuatif sebab investor akan sulit membuat prediksi atas earnings dan ekspektasi dividen investor menjadi tidak stabil.

Praktik income smoothing dapat muncul kerena manajemen memilki keleluasaan dalam memilih metoda akuntansi. Keleluasaan semacam ini dapat digunakan manajemen untuk memilih metoda-metoda tertentu yang sesuai dengan kepentingannya. Praktik income smoothing dapat dilakukan melalui beberapa cara antara lain: 1) perataan melalui waktu terjadi event lain atau pengakuan terjadinya suatu event. Pihak management dapat menentukan waktu transaksi melalui kebijakan management sendiri (accrual), misalnya pengeluaran biaya riset dan pengembangan, sehingga variasi earnings dapat dikurangi; 2) income smoothing melalui alokasi untuk beberapa perioda tertentu. Manajemen memiliki kewenangan untuk mengalokasikan pendapatan atau biaya tertentu untuk beberapa perioda; dan 3) perataan melalui klasifikasi. Manajemen memiliki kewenangan atau kebijakan sendiri untuk mengklasifikasikan pos-pos rugi laba dalam katagori yang berbeda (antara ordinary items dengan extraordinary items).

Berbagai penelitian untuk mendeteksi adanya income smoothing banyak dilakukan. Barnea et al. (1976) serta Godfrey dan Jones (1999) menemukan income smoothing melalui klasifikasi pos dalam laporan rugi-laba. Mones (1987) mendeteksi income smoothing melalui perubahan metoda akuntansi yang digunakan oleh perusahaan. Penelitian-penelitian sebelumnya juga menemukan bahwa beberapa instrumen yang banyak digunakan untuk melakukan income smoothing adalah dividend income, perubahan-perubahan dalam kebijakan akuntansi, investment tax credit, depreciation dan fixed changes, discretionary accounting decisions, exchange differences, accounting classification, serta reserves dan provisions (Ashari et al., 1994: 292).

Hapworth (1953) sebagaimana yang dikutip Ashari et al. (1994) menyebutkan bahwa ada beberapa alasan mengapa manajemen melakukan praktik semacam itu antara lain: 1) manajemen dapat mengurangi utang pajak (tax liability); 2) laba yang rata akan dapat menambah keyakinan investor terhadap perusahaan sebab earnings yang stabil akan juga menghasilkan kebijakan dividen yang stabil pula; 3) income smoothing akan dapat meningkatkan hubungan baik antara manajemen dengan pekerja; dan 4) income smoothing akan memberikan dampak psikologis sebab akan menurunkan harapan yang terlalu optimis dan menaikkan harapan terlalu pesimistik. 
Penelitian yang mendukung adalah Sweeney (1994) dalam Scott (2000) menemukan seringkali earnings management dilakukan ketika perusahaan menghadapi paksaan dari kreditor dengan cara mengubah metoda akuntansinya. Adanya tingkat laba yang stabil dari tahun ke tahun akan menimbulkan kesan bahwa peusahaan akan mampu memenuhi semua kontrak utang yang telah dibuat. Perusahaan dengan utang yang lebih kecil dan laba yang berfluktuasi akan memiliki risiko untuk tidak memenuhi perjanjian utang jika dibandingkan dengan perusahaan dengan utang yang lebih besar dengan laba yang berfluktuasi pula. Dengan kata lain, dalam keadaan laba berfluktuasi, perusahaan dengan utang besar akan memiliki kemungkinan tidak memenuhi perjanjian utang jika dibandingkan dengan perusahaan dengan utang yang kecil. Dengan demikian, perusahaan dengan utang besar akan memiliki insentif yang lebih besar untuk melakukan earnings management bila dibandingkan dengan perusahaan dengan utang rendah.

Defond dan Jiambalvo (1994) dalam Scott (2000) meneliti hubungan antara utang dengan earnings management. Sampel di NYSE perioda 1980-1990. Hasil penelitian menunjukkan terdapat hubungan antara rasio utang dengan praktik earnings management. Hasil penelitian ini diperkuat Yurianto (2000) dengan sampel negara Asia Tenggara yaitu Indonesia, Singapura, Malaysia dan Thailand perioda 1986-1995.

Market share (pangsa pasar) digunakan untuk sebagai proksi biaya politik atau kemampuan perusahaan untuk mendapatkan tingkat monopoli tertentu. Perusahaan dengan tingkat pangsa pasar yang tinggi akan akan memiliki potensi biaya politik yang tinggi seperti penghapusan subsidi dan pengenaan tarif tertentu (Jones, 1991; serta Godfrey dan Jones, 1991). Perusahaan yang memiliki pangsa pasar yang tinggi cenderung melakukan earnings management daripada harus menekan kenaikan earnings. Hal ini disebabkan selain menghindari biaya politik, perusahaan juga masih menginginkan hubungan baik dengan konsumen, pekerja, dan pemasok. Hal tersebut diperkuat Moses (1987) bahwa pangsa pasar tinggi berhubungan positif dengan earnings management.

Pengaruh profitabilitas terhadap utang adalah Arhibald (1967) dalam Ashari et al. (1994) menyatakan bahwa perusahaan yang memiliki profitabilitas yang rendah cenderung melakukan earnings management. Hal ini disebabkan adanya pengaruh buruk yang lebih besar atas aliran pendapatan pada perusahaan dengan laba rendah daripada perusahaan dengan laba tinggi. Oleh karea itu perusahaan dengan profitabilitas rendah akan cenderung melakukan earnings management jika dibandingkan perusahaan yang mempunyai profitabilitas tinggi. Ashari et al. (1994) membuktikan bahwa profitabilitas perusahaan yag melakukan earnings management lebih rendah secara signifikan daripada perusahaan yang tidak melakukan earnings management. Penelitian yang sama di Indonesia dilakukan Zuhroh dan Jin (1997). Sedangkan penelitian yang menguji pengaruh size terhadap earnings management adalah Ilmainir (1993), Zuhroh (1996), Jin (1997), serta Ghofar (2001). Review penelitian ada dalam Tabel 1. Berdasarkan beberapa penelitian di atas, maka hipotesis alternatif sebagai berikut:

$\mathrm{H}_{\mathrm{A}}$ : Ada pengaruh earnings management terhadap kinerja.

Tabel 1

Review Penelitian Yang Mendukung

\begin{tabular}{|c|c|c|c|c|c|c|}
\hline \multirow[t]{3}{*}{ No. } & \multirow[t]{3}{*}{ Nama Peneliti/Tahun } & \multicolumn{5}{|c|}{ Variabel Yang Diuji } \\
\hline & & \multicolumn{4}{|c|}{ Earnings Management } & \multirow{2}{*}{ KINERJA } \\
\hline & & EM & PP & PROFIT & SIZE & \\
\hline 1. & $\begin{array}{l}\text { Sweeney (1994) dalam Scott (2000), Defond dan } \\
\text { Jiambalvo (2000) dalam Scott (2000), serta } \\
\text { Yunianto (2000) }\end{array}$ & V & - & - & - & - \\
\hline 2. & $\begin{array}{l}\text { Moses (1987), Godfrey dan Jones (1991), serta } \\
\text { Jones (1991) }\end{array}$ & V & $\mathrm{V}$ & - & - & - \\
\hline 3. & $\begin{array}{l}\text { Ashari et al. (1994), Zuhroh (1996), serta Jins } \\
\text { (1997) }\end{array}$ & V & - & V & - & - \\
\hline
\end{tabular}




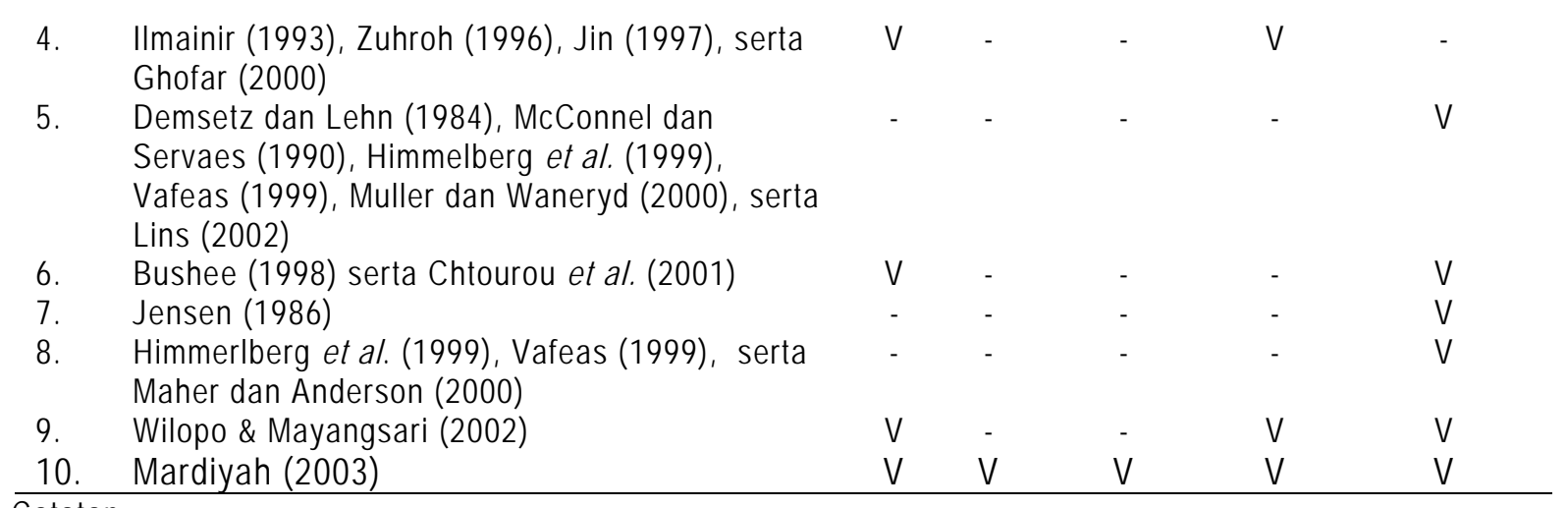

Catatan:

$\mathrm{V}=$ variabel yang digunakan $\quad$ - = variabel yang tidak digunakan

Keterangan:

EM = Earnings Management $\mathrm{PP}=$ Pangsa Pasar (Market Share) Profit $=$ Profitabilitas

\section{METODA PENELITIAN}

3. 1. Data

3. 1. 1. Sampel Penelitian

Sampel penelitian ini adalah perusahaan yang terdaftar di Bursa Efek Jakarta. Sampel yang diteliti hanya perusahaan yang nonregulasi seperti penelitian Dunn et al. (2000) dalam Wilopo dan Mayangsari (2002) ada dalam Lampiran 1.

\section{1. 2. Sumber Data dan Teknik Pengambilan Data}

Penelitian ini menggunakan data panelan (pooled data) tahun 1997-2001. Pemilihan sampel dilakukan dengan menggunakan metoda penyampelan bersasaran (purposive sampling) dengan kriteria sampel sebagai berikut: a) perusahaan sahamnya tetap beroperasi sampai bulan Desember 2001, serta mempublikasikan laporan keuangan secara rutin; b) perusahaan tidak pernah mengalami terawadaftar (delisting) dari Bursa Efek Jakarta sehingga bisa terus menerus melakukan perdagangan saham di BEJ selama perioda estimasi; c) perusahaan tidak menghentikan aktivitasnya di pasar bursa, tidak menghentikan operasinya, dan tidak melakukan penggabungan usaha; d) perusahaan tidak berubah status sektor industrinya; serta e) perusahaan mempunyai laporan keuangan yang berakhir 31 Desember.

Data keuangan perusahaan diperoleh dari Bursa Efek Jakarta, website Jakarta Stock Exchange, data pasar berasal dari UGM Database dan JSX Monthly Statistics, data struktur kepemilikan manajerial diperoleh dari website Jakarta Stock Exchange, Capital Market Directory 2001, serta catatan laporan keuangan perusahaan, serta data lainnya diperoleh dari STIE Malangkuçeçwara Malang. JSX Factbook, JSX Statistics tahunan/bulanan, Laporan BAPEPAM, dan JPMI.

\section{2. Pengukuran Variabel}

\section{2. 1. Variabel Dependen}

Kinerja. Proksi kinerja adalah Economic Value Added (EVA). Hasil EVA yang positif menunjukkan adanya nilai tambah yang terjadi di perusahaan. Prosedur menghitung EVA adalah sebagai berikut:
a) EVA= (adjusment NOPAT - CapChg + Acct.Adj)/assets t-1
Keterangan:
NOPAT : laba (earnings) setelah pajak
CapChy : WACC (weighted average cost of capital) $x$ modal pemegang saham
Acct.Adj : aset total + cadangan yang diestimasi
Assets t-1 : nilai aset pada perioda sebelumnya 
b) WACC $=\operatorname{wdkd}(1-T)+$ wpskps + wcskcs (penyesuaian item-item)

Keterangan:

$\mathrm{W}_{\mathrm{d}} \mathrm{k}_{\mathrm{d}} \quad$ : bobot dana dari utang jangka panjang

T : pajak

$W_{p s} k_{p s} \quad$ : bobot dana dari saham preferen

$\mathrm{W}_{\mathrm{cs}} \mathrm{K}_{\mathrm{cs}} \quad$ : bobot dana dari saham biasa

\section{2. 2. Variabel Independen}

Earnings management. Deteksi earnings management menggunakan model Jones yang dimodifikasi (1991) karena Dechow et al. (1995) menyatakan model Jones yang telah dimodifikasi memberikan kekuatan statistis yang tinggi untuk mendeteksi adanya earnings management ada jika terdapat discretionary accruals yang signifikan. Prosedur yang digunakan seperti Dechow et al. (1995), Wilopo dan Mayangsari (2002), serta Mardiyah (2003) sebagai berikut:

a) Menghitung total akrual seperti penelitian Healy (1985):

$\mathrm{TA}_{\mathrm{it}}=\left(\Delta \mathrm{CA}_{\mathrm{t}}-\Delta \mathrm{CL}_{\mathrm{t}}-\Delta \mathrm{Cash}_{\mathrm{t}}-\mathrm{Dep}_{\mathrm{t}}\right) / \mathrm{A}_{\mathrm{t}-1}$

\section{Keterangan:}

$\Delta \mathrm{CA}_{\mathrm{t}} \quad$ : perubahan aset lancar (current assets) selain kas

$\Delta \mathrm{CL}_{\mathrm{t}} \quad$ : perubahan utang lancar (current liabilities)

$\Delta$ Cash $_{\mathrm{t}} \quad$ : perubahan kas dan ekuivalennya

Dep $_{\mathrm{t}} \quad$ : kos depresiasi dan amortisasi

$A_{t-1} \quad$ : aset total tahun sebelumnya

b) Mendeteksi discretionary accruals dan non-discretionary accruals dengan persamaan berikut:

$T A_{i t} / T A_{t-1}=\alpha_{i}\left(1 / A_{i t-1}\right)+\beta_{1 i}\left(\Delta R E V_{i t} / A_{i t-1}\right)+\beta_{2 i}\left(P P E_{i t-1} / A_{i t-1}\right)+\varepsilon_{i t}$

Keterangan:

$\mathrm{TA}_{\text {it }} \quad$ : akrual total pada tahun $\mathrm{t}$ untuk perusahaan $\mathrm{i}$

$\triangle R E V_{i t}$ : pendapatan tahun $t$ dikurangi pendapatan pada tahun t-1 untuk perusahaan i

$P P E_{i t-1}$ : aset tetap dan perlengkapan bruto pada akhir tahun t-1 untuk perusahaan $\mathrm{i}$

$A_{\text {it-1 }} \quad$ : aset total pada akhir tahun t-1 untuk perusahaan i

$\varepsilon_{\text {it }} \quad:$ galat (error term) pada tahun t untuk perusahaan $\mathrm{i}$

i : : perusahaan $1,2,3, \ldots ., n$

$\mathrm{t} \quad$ : tahun ke $1,2,3, \ldots . . \mathrm{t}$ (perioda estimasi untuk perusahaan i)

c) Mencari abnormal accruals $\left(A A_{i p}\right)$ dengan rumus sebagai berikut:

$A A_{i p}=T A_{i p} / A_{i p-1}-\left(\alpha_{i}\left[1 / A_{i t-1}\right]+\beta_{1 i}\left[\Delta R E V_{i t} / A_{i t-1}\right)+\beta_{2 i}\left[P P E_{i t-1} / A_{i t-1}\right]\right)$

d) Pengujian signifikansi discretionary accruals dengan menggunakan rumus:

\section{$\mathrm{Z}=\frac{\text { rata-rata discretionary accruals }}{\text { Deviasi standar discretionary accruals } / \sqrt{ } \mathrm{n}}$}

Jika nilai $\mathrm{Z}$ di atas nilai t tabel maka $\mathrm{H}_{0}$ ditolak dengan kata lain discretionary accruals yang ada secara statistik signifikan. Jika manajeman melakukan earnings management maka akan terdapat discretionary accruals (residual) positif maupun negatif yang signifikan.

\section{2. 3. Variabel Kontrol}

Size. Variabel size menggunakan kategoris (dummy) seperti penelitian Ang dan McConnell (1982); Crutchley dan Hansen (1989); Gaver dan Gaver (1993), Ross dan Jaffe (1999: 409); serta Mahadwartha dan Hartono (2002). Ukuran perusahaan (firm size) diukur dengan ekuitas saham yang 
disusun urut besarnya dan dipilih $50 \%$ teratas bernilai $0(D=0)$ dan $50 \%$ terbawah bernilai satu $(D=1)$. Hal ini dilakukan karena data antar perusahaan (crosssectional) bila di panelan (pooling) menimbulkan bias antar perusahaan (Murphy, 1985).

\section{Metoda Analisis Data}

\section{1. Pengujian Asumsi Klasik}

Agar model regresi tersebut memenuhi syarat BLUE harus diuji dengan asumsi klasik yaitu uji multikolinearitas, autokorelasi, dan heteroskedastisitas. Model ini merupakan model yang menggunakan lebih dari satu variabel independen guna menduga variabel dependen. Untuk mengetahui arti pengaruh antar variabel dependen dengan independen perlu melakukan pengujian hipotesis, baik secara parsial maupun simultan. Yang secara otomatis di komputer akan disajikan uji $F, t$, dan $R^{2}$.

Dalam mengunakan model regresi perlu memperhatikan adanya kemungkinan penyimpangan asumsi klasik, karena pada hakekatnya jika asumsi dalam uji diagnostik ini tidak dipenuhi maka variabel-variabel yang menjelaskan akan menjadi tidak efisien. Menurut Gujarati (1995: 279) ada 7 asumsi klasik, namun hanya 3 asumsi yang dianggap penting oleh para ahli ekonomi yaitu:

a). Tidak terjadi multikolinearitas antar variabel independen;

b). Tidak terjadi autokorelasi antar komponen penganggu; dan

c). Tidak terjadi heteroskedasitas antara komponen penganggu berarti varian tiap unsur pengganggu harus konstan atau memenuhi syarat homoskedasitas yaitu: $E\left(\mu_{i}^{2}\right)=0$

Dibawah ini adalah cara untuk mendeteksi munculnya gejala penyimpangan dari ketiga asumsi klasik di atas.

\section{1. 1. Multikolinearitas}

Menurut Gujarati (1995: 293-301) salah satu cara untuk mendeteksi adanya gejala multikolinearitas adalah jika $\mathrm{R}^{2}$ cukup tinggi (lebih dari $80 \%$ ) tetapi tidak satupun atau sedikit koefisien regresi orisinal yang signifikan. Apabila besarnya koefisien parsial diatas 0,80 hal ini dapat menunjukkan adanya korelasi antar variabel independen. Jika $r>0,8$ berarti multikol berbahaya dan signifikan (nilai $p<\alpha$ ) berarti terjadi multikol, sebaliknya jika (nilai $p>\alpha$ ) berarti tidak signifikan sehingga tidak terjadi multikol.

\section{1. 2. Autokorelasi}

Salah satu cara untuk mendeteksi ada tidaknya autokorelasi adalah dengan menggunakan Durbin Watson. Ada beberapa kriteria untuk mendeteksi autokorelasi, yaitu:

(1). Jika nilai $d>\left(4-d_{L}\right)$, berarti autokorelasi negatif.

(2). Jika nilai $d<d_{L}$, berarti tidak ada autokorelasi positif.

(3). Jika $d_{u}<d<\left(4-d_{u}\right)$, berarti tidak ada autokorelasi.

(4). Jika $d_{U}<d<d_{L}$ dan $\left(4-d_{U}\right)<d<\left(4-d_{L}\right)$, berarti tidak menghasilkan simpulan.

Nilai d menunjukkan nilai Durbin Watson, du merupakan nilai batas atas dari tabel, dan $d_{L}$ menunjukkan nilai batas bawah dari tabel. Jika d mendekati 2 maka Ho diterima atau tidak signifikan, artinya antara varibel tersebut independen (nonautokorelasi)

\section{1. 3. Heteroskedastisitas}

Heteroskedastisitas adalah salah satu penyimpangan dari asumsi model regresi linier klasik yang mengatakan bahwa gangguan atau galat (error) semuanya mempunyai varian yang sama (homoskedasitas). Untuk mendeteksi adanya heteroskedasitas dapat dilakukan dengan cara uji korelasi Rank Sperman.

\section{1. 4. Uji Kenormalan Galat Regresi}

Uji kenormalan galat regresi dilakukan dengan menggunakan uji Kolmogorov-Smirnov. Jika galat regresi tidak signifikan berarti galat regresi normal (Hair et al., 1995). 


\section{2. Metoda Analisa dan Pengujian Hipotesis}

Berdasarkan penelitian sebelumnya dan teori yang ada (Jensen dan Meckling, 1976; Defond dan Jiambalvo (1994) dalam Scott (2000), Sweeney (1994) dalam Scott (2000), Yurianto (2000), serta Mardiyah, (2003)), maka model secara matematis dijabarkan dalam suatu persamaan regresi dengan menggunakan sebagai berikut:

Keterangan:

$\operatorname{Kin}_{i, t}=\alpha_{0}+\beta_{1} E M_{i, t}+\beta_{2} \operatorname{Size}_{i, t}+e_{i}$

$\mathrm{Kin}_{\mathrm{i}, \mathrm{t}} \quad$ : kinerja

$\mathrm{SKM}_{\mathrm{i}, \mathrm{t}}$ : earnings management

Size $_{i, t}$ : ukuran perusahaan

$\alpha_{0} \quad$ : konstan

Penggunaan metoda regresi linier berganda ini adalah untuk menguji hipotesis yang menyatakan bahwa diduga ada pengaruh yang berarti antara earnings management dengan kinerja secara individual. Setelah model penelitian memenuhi ketiga asumsi klasik di atas, maka dilakukan pengujian hipotesis dengan langkah-langkah sebagai berikut:

a). Merumuskan hipotesis penelitian menjadi hipotesis statistik.

$H_{0}: b_{1}=0$, artinya tidak ada pengaruh yang signifikan dari variabel $X$ terhadap variabel $Y$.

$H_{a}: b i \neq 0$, artinya terdapat pengaruh yang signifikan dari variabel $X$ terhadap variabel $Y$.

b). Menetapkan tingkat signifikan $\alpha=5 \%$ atau $10 \%$.

c). Menguji pengaruh $X$ secara parsial terhadap $Y$, dengan uji t. Uji t digunakan untuk menentukan tingkat signifikansi secara parsial (individu) setiap variabel independen $(X)$ terhadap variabel dependen $(Y)$. Nilai uji t ini secara rutin juga telah dihitung oleh komputer. Bila nilai $p>\alpha$ berarti $H_{0}$ diterima, yang artinya variabel $X$ tidak berpengaruh secara signifikan terhadap variabel y (hipotesa tidak didukung). Sebaliknya bila nilai $p<\alpha$, berarti $H_{a}$ diterima, artinya variabel $X$ berpengaruh terhadap variabel $Y$ (hipotesis didukung).

\section{HASIL PENELITIAN}

\section{1. Statistik Deskriptif}

Statistik deskriptif ada pada Tabel 2. Rata-rata struktur kepemilikan manajerial menunjukkan nilai 18,50 dan deviasi standar sebesar 5,72. Nilai rata-rata lebih besar daripada deviasi standar menandakan tidak ada masalah outlier dengan earnings management. Rata-rata kinerja menunjukkan nilai 16,41 dan deviasi standar sebesar 7,01. Nilai rata-rata lebih besar daripada deviasi standar menandakan tidak ada masalah outlier dengan kinerja.

Tabel 2

Statistik Deskriptif

\begin{tabular}{lrc}
\hline Variabel & Rata-Rata & Deviasi Standar \\
\hline Earnings Management & 18,50 & 5,72 \\
Kinerja & 16,41 & 7,01 \\
\hline
\end{tabular}

\section{2. Hasil Pengujian Asumsi Klasik}

\section{2. 1. Hasil Pengujian Gejala Multikolinearitas}

Pengujian asumsi pertama dengan multikolinieritas, dilakukan dengan melihat korelasi Pearson Correlation antar variabel independen sebesar 0,218. Dari hasil matrik korelasi tersebut ternyata tidak ada variabel independen yang koefisien korelasinya lebih besar atau sama dengan 0,80 . Sehingga dapat dikatakan model regresi tersebut telah memenuhi asumsi pertama, yaitu tidak terjadi multikolinearitas antar variabel independen (multikol tidak berbahaya). 


\section{2. 2. Hasil Pengujian Gejala Heteroskedasitas}

Uji gejala heteroskedasitas dilakukan dengan melihat uji t secara parsial sebesar 0,321 . Hasilnya menunjukkan bahwa struktur kepemilikan manajerial tidak signifikan pada $\alpha=5 \%$ sehingga terjadi homoskedasitas.

\section{2. 3. Hasil Pengujian Gejala Autokorelasi}

Uji gejala autokorelasi dilakukan dengan melihat hasil Durbin Watson nilainya sebesar 2,222. Dengan demikian tidak ada korelasi serial diantara disturbance terms, sehingga variabel tersebut independen (nonautokorelasi). Dari hasil pengujian asumsi OLS diatas, maka dapat disimpulkan bahwa persamaan regresi yang dibuat semula telah memenuhi syarat sebagai Best Linear Unbiased Estimators (BLUE).

\section{2. 4. Hasil Kenormalan Galat Regresi}

Berdasarkan hasil uji kenormalan galat regresi dengan menggunakan KolmogorovSmirnov= 1,081 dengan nilai $p=0,456$ menunjukkan hasil tidak signifikan pada tingkat $\alpha=5 \%$. Ketidaksignifikanan ini berarti data normal (Hair et al., 1995).

\section{3. Hasil Pengujian Hipotesis}

Hasil pengujian hipotesis disajikan dalam Tabel 3.

Tabel 3

Hasil Regresi Antara Struktur Kepemilikan Manajerial Terhadap Kinerja

\begin{tabular}{lccr}
\hline & Kons & EM & Size \\
\hline Uji t & 2,011 & 2,145 & 2,222 \\
(nilai $p)$ & $(0,028)$ & $(0,000)$ & $(0,005)$ \\
& $\mathrm{R}^{2}$ & Adj R $\mathrm{R}^{2}$ & Uji F
\end{tabular}

\begin{tabular}{rrr}
0,499 & 12,320 \\
0,423 & $(0,000)$ \\
\hline
\end{tabular}

Analisis yang dilakukan berdasarkan Tabel 3 adalah sebagai berikut:

1. $\mathrm{b}_{\mathrm{i}}=6,229-\mathrm{E} 05+7,655-\mathrm{E} 03_{\mathrm{EM}}+2,181 \mathrm{E}-02_{\text {SIZE }}+\mathrm{e}$

2. $R_{\text {square }}=0,499$ artinya kinerja dipengaruhi earnings management sebesar $49,9 \%$ sedangkan $50,1 \%$ dipengaruhi oleh variabel lain (galat).

3. Dengan melihat uji $F=12,320$ dengan nilai $p=0,000$ berarti signifikan pada $\alpha=5 \%$, berarti model tersebut fit.

Ada pengaruh earnings management terhadap kinerja. Nilai uji $t=2,145$ dengan nilai $p=$ 0,000 berarti hipotesis ini signifikan pada $\alpha=5 \%$. Simpulan hipotesis ini mendukung Barnea et al. (1976); Mones (1987); Ilmainir (1993); Hapworth (1953) dalam Ashari et al. (1994); Arhibald (1967) dalam Ashari et al. (1994); Ashari et al. (1994: 292); Zuhroh (1996), Jin (1997); Godfrey dan Jones (1999); Defond dan Jiambalvo (1994) dalam Scott (2000); Sweeney (1994) dalam Scott (2000); Ghofar (2001); Tarjo (2002); serta Mardiyah (2003) yang menyatakan ada pengaruh earnings management terhadap kinerja.

\section{SIMPULAN}

Tujuan penelitian ini adalah memberikan bukti empiris bahwa pengaruh earnings management terhadap kinerja. Penelitian ini menggunakan 153 sampel tahun 1997-2001. Pemilihan sampel didasarkan penyampelan bersasaran (stratified random sampling). Sedangkan data yang digunakan data sekunder (archival). Alat analisis yang digunakan untuk menguji hipotesis yaitu regresi berganda.

Hasil penelitian ini adalah ada pengaruh earnings management terhadap kinerja. Penelitian ini mendukung Barnea et al. (1976); Mones (1987); Ilmainir (1993); Hapworth (1953) dalam Ashari et al. (1994); Arhibald (1967) dalam Ashari et al. (1994); Ashari et al. (1994: 292); Zuhroh (1996), Jin 
(1997); Godfrey dan Jones (1999); Defond dan Jiambalvo (1994) dalam Scott (2000); Sweeney (1994) dalam Scott (2000); Ghofar (2001); Tarjo (2002); serta Mardiyah (2003) yang menyatakan ada pengaruh earnings management terhadap kinerja.

\section{1. Keterbatasan Penelitian}

1. Penelitian di Indonesia dibatasi hanya Bursa Efek Jakarta dengan alasan BEJ merupakan bursa efek di Indonesia dan telah cukup berkembang.

2. Sampel hanya memasukkan jenis industri pemanufakturan dengan seluruh sub katagori, sehingga jenis industri lain tidak tercover dalam penelitian ini sangat memungkinkan mengganggu intepretasi penelitian.

3. Rentang waktu pengamatan juga masih dianggap peneliti terlalu singkat, kebanyakan penelitian di luar negeri menggunakan waktu pengamatan selama sepuluh tahun.

\section{2. Implikasi Penelitian Yang Akan Datang}

Hasil penelitian ini minimal dapat mendorong dan memicu dilakukan penelitian-penelitian berikutnya. Dengan mempertimbangkan keterbatasan-keterbatasan yang ada, diharapkan penelitian yang akan datang memperbaiki faktor-faktor seperti sampel yang digunakan seluruh jenis industri, rentang waktu pengamatan seperti kebanyakan penelitian di luar negeri menggunakan waktu pengamatan selama sepuluh tahun, faktor-faktor yang mempengaruhi earnings management digali lebih lanjut teorinya, dan penggunaan proksi lain untuk mengukur kinerja agar hasil penelitian robust.

\section{DAFTAR PUSTAKA}

Alderson, Michael J. dan Brian L. Betker, (1997), "The Long Run Performance of Companies That Withdraw Seasoned Equity Offerings", Working Paper, September 1997.

Ang, J. J. Chua dan McConnell, J., (1982), "The Administrative Costs of Corporate Bankruptcy: A Note," The Journal of Finance, h. 219-226.

Ashari, N.; Hian C. K.; Soh L. T.; dan Wei H. W., (1994), "Factor Affecting Income Smoothing Among Listed Companies in Singapura," Accounting and Bussines Research, Vol. 24, No. 96 , h. $291-301$

Barnea, Amir; Joshua Ronen; dan Simcha Sadan, (1976), "Classificatory Smoothing of Income With Extraordinary Items," The Accounting Review, January, h. 111-122.

Beneish, Messod D., (2001), "Earnings Management: A Perspective," Working Paper, April.

Bushee, Brian, (1998), "Institutional Investors, Long Term Investment and Earnings Management," Social Science Research Network, January, h. 1-30.

Candy, (2002), "Analisis Kinerja Perusahaan yang Melakukan Seasoned Equity Offerings: Studi Kasus di Bursa Efek Jakarta," Skripsi, Fakultas Ekonomi, UAJY, Yogyakarta.

Chambers, Dennis J., (1999), "Earnings Management and Capital Market Misallocation," Working Paper, December.

Chtourou, Sonda Marrkkchi, (2001), "Corporate Governance and Earnings Management," Social Science Research Network, April, h. 1-35. 
Crutchley, Claire E. dan Hansen, Robert S., (1989), "A Test of the Agency Theory of Managerial Ownership, Corporate Leverage, and Corporate Dividends," Financial Management, Winter, h. 36-46.

Dechow, P. M.; R. G. Sloan; dan P. Sweeney, (1995), "Detecting Earnings Management," The Accounting Review, Vol. 70, h. 193-225.

-------, Jowell Sabino, dan Richard G. Sloan, (1998), "Implications of Nondiscretionary Accruals for Earnings Management and Market-Based Research," Working paper, January.

Demsetz, H. dan Lehn, K., (1985), "The Structure of Corporate Ownership: Causes and Consequences," Journal of Political Economy, Vol. 93, h. 1155-1177.

Dubois, Michel dan Pierre Jeanneret, (2000), "The Long-Run Performance of Seasoned Equity Offerings With Rights," Working paper, Januari 2000.

DuCharme, Larry L.; Paul H. Malatesta; dan Stephan E. Sefcik, (2000), "Earnings Management: IPO Valuation and Subsequent Performance," Working Paper, 8 August.

Espenlaub, Susanne, (1999), "Discussion of the Life Cycle of Initial Public Offering Firm," Journal of Business Finance and Accounting, 26 (9) \& (10), Nov./Dec.

Gaver, J. J. dan Gaver, K. M., (1993), "Additional Evidence on the Association between the Investment Opportunity Set and Corporate Financing, Dividend, and Compensation Policies," Journal of Accounting and Economics, h. 125-160.

Ghofar, Abdul (2001), "Pengaruh Size, Pangsa Pasar, Konsentrasi Kepemilikan, Profitabilitas, dan Hutang terhadap Status Perataan Laba," Tesis Pascasarjana Universitas Gadjah Mada, Yogyakarta.

Godfrey, Jayne M. dan Jones, Kerrie L., (1999), "Political Influences on Income Smoothing Via Extraordinary Item Classification," Journal Accounting and Finance, Vol. 39, h. 229-254.

Gujarati, D. N., (1995), Basic Econometrics, $3^{\text {rd }}$ ed., Singapore: McGraw-Hill, Inc.

Gumanti, Tatang Ary, (2000), "Earnings Management Dalam Penawaran Saham Perdana di Bursa Efek Jakarta," Seminar Nasional Akuntansi (SNA) III.

Hair, Jr., J. F; R.E. Anderson; R.L. Tatham; dan W. C. Black, (1995), Multivariate data analysis with readings, Third edition, New York, NY: Micmillan Publishing Co.

Hall, Steven C. dan William W. Stammerjohan, (1997), "Damage Awards and Earnings Management in The Oil Industry," The Accounting Review, 72 (1), January.

Hartono, J. dan Na'im, Ainun, (1998), "The Effect of A Legal Process on Management of Accruals: Further Evidences on Management of Earnings," Jurnal Ekonomi dan Bisnis Indonesia, 13 (2). 
Healy, Paul M., (1985), "The Effect of Bonus Schemes on Accounting Decisions," Journal of Accounting and Economics 7, h. 85-107.

dan James M. Wahlen, (1998), "Review of the Earnings Management Literature and Its Implications for Standard Setting," Working paper.

Himmelberg, Charles P.; R Glen Hubbard; dan Darius Palia, (1999), Understanding the Determinants of Managerial Ownership and the Link Between Ownership and Performance," Journal of Financial Economics, Vol. 53, h. 353-384.

Ilmaniar, (1993), "Perataan Laba dan Faktpr-Faktor Pendorongnya Pada Perusahaan Publik di Indonesia," Tesis, Pascasarjana Universitas Gadjah Mada, Yogyakarta.

Jain, Bharat A. dan Omesh Kini, (1994), "The Post-Issue Operating Performance of IPO Firms," Journal of Finance, December.

Jensen, Michael C. dan Meckling, William H., (1976), "Theory of The Firm: Managerial Behavior, Agency Costs and Ownership Structure," Journal of Financial Economics, Vol. 3, h. 82-137.

Jensen, Michael C., (1986), "Agency Cost of Free cash Flow, Corporate Finance, and Takeover," American Economic Review, Vol. 76, h. 323-339.

Jin, Liaw She, (1997), "Faktor-Faktor yang Mempengaruhi Praktek Perataan Laba Pada Perusahaan yang Terdaftar di Bursa Efek Jakarta," Tesis Pascasarjana Universitas Gadjah Mada, Yogyakarta.

Jones, (1991), "Earnings Management During Import Relief Investigation," Journal of Accounting Research, Autumn, h. 193-228.

Lins, Karl V., (2002), "Equity Ownership and Firm Value in Emerging Markets," Social Science Research Network, April, h. 1-47.

Loughran, Tim., dan Ritter, Jay R., (1997), "The Operating Performance of Firms Conducting Seasoned Equity Offerings," The Journal of Finance, 1997.

Mahadwartha, Putu Anom dan Hartono, Jogiyanto, (2002), "Uji Teori Keagenan dalam Hubungan Interdependensi Antara Kebijakan Hutang dan Kebijakan Dividen," Simposium Nasional Akuntansi V, Semarang, h. 635-647

Maher, Maria dan Anderson,Thomas, (2000), "Corporate Governance: Effects on Firm Performance and Economic Growth," Social Science Research Network, February, h. 1-40.

Mardiyah, Aida A., (2003), "Pengaruh Struktur Kepemilikan Manajerial, Earnings Management, Free Cash Flow Terhadap Utang Dan Kinerja," Dipresentasikan dalam Program Semique STIE MALANGKUÇEÇWARA Malang.

(2003), "Hubungan Withdrawn Initial Public Offering (WIPO), Seasoned Equity Offerings (SEO), dan Earnings Management dengan Initial Return," Simposium Nasuonal Akuntansi VI, UNAIR, Surabaya 
McConnell, John J. dan Servaes, Henri, (1990), "Additional Evidence on Equity Ownership and Corporate Value," Journal of Financial Economics Vol. 27, h. 595-612.

McLaughlin, Assem S. dan Gopala K.V., (1996), "The Operating Performance of Seasoned Equity Issuers: Free Cash Flow and Post Issue Performance," Financial Management, Vol.25, 1996.

Moses, Dauglas O., (1987), "Income smoothing and Incentives: Empirical Tests Using Accounting Changes," The Accounting Review, Vol, LXII, No. 2.

Muller, Holger dan Waneryd, Karl, (2000), "Inside versus Outside Ownership: A Political Theory of the Firm," Social Science Research Network, h. 1-22.

Murphy, Kevin J., (1985), "Corporate Performance Managerial Remunation: An Empirical Analysis," Journal of Accounting and Economics, h. 11-41.

Na'im, Ainun dan Hartono, J., (1996), "The Effect of Antitrust Investigations on Management of Earnings," Kelola, No. 13/VI.

Perry, Susan E. dan Thomas H. William, (1994), "Earnings Management Preceding Management Buyout Offers," Journal of Accounting and Economics, 18.

Rangan, Srinivasan, (1998), "Earnings Management and the Performance of Seasoned Equity Offerings," Journal of Financial Economics, 50.

Richardson, Vernon J., (1998), "Information Asymmetry and Earnings Management: Some Evidence," Working paper, 30 March.

Ritter, Jay R., (1991), "The Long Run Performance of Initial Public Offering," Journal of Finance, 46, h. $3-27$.

Ross, S.; R. W. Westerfield; dan Jaffe, J., (1999), Corporate Finance, $5^{\text {th }}$ edition, Irwin McGraw-Hill.

Scott, William R., (2000), Financial Accounting Theory, $2^{\text {nd }}$ Ed., Prentice Hall Canada Inc.

Setiawati, Lilis, (2001), "Rekayasa Akrual untuk Meminimalkan Pajak," Simposium Nasional Akuntansi (SNA) IV, Bandung.

Sulistyanto, H. Sri dan Midiastuti, P. P., (2002), "Seasoned Equity Offerings: Benarkah Underperformance Setelah Penawaran?" Simposium Nasional Bidang IImu Ekonomi, Akuntansi, dan Manajemen, UAJY, Yogyakarta

Tarjo, (2002), "Analisa Free Cash Flow dan Kepemilikan Manajerial Terhadap Kebijakan Utang Pada Perusahaan Mempublik di Indonesia," Tesis Pascasarjana Universitas Gadjah Mada, Yogyakarta

Teoh, Siew Hong; T. J. Wong; dan Gita R. Rao, (1997), "Are Accruals During An Initial Public Offering Opportunistic?" Working Paper, July. 
-------, Ivo Welch; dan T.J. Wong, (1998) "Earnings Management and the Underperformance of Seasoned Equity Offerings," Journal of Financial Economics, 1998.

Traill, Marcus dan Ed Vos, (2001), "Do Seasoned Equity Offerings Really Underperform in the Long Run? Evidence from New Zealand," Working Paper, 2001.

Trisnawati, Rina, (1998), "Pengaruh Informasi Prospektus Terhadap Return Saham Di Pasar Perdana," Tesis S2 Pasca Sarjana, UGM Yogyakarta..

Vafeas, Nikos, (1999), "Board Meeting Frequency and Firm Performance," Journal of Financial Economics, Vol. 53, h. 113-142.

Wilopo dan Mayangsari, (2002), "Pengaruh Struktur Kepemilikan, Perilaku Manajemen Laba, Free Cash Flow Hyphotesis dan Economic Added: Pendekatan Path Analysis," Jurnal Ekonomi dan Bisnis Indonesia, Vol. 17, No. 4, h. 473-495.

Yurianto, Priyo Sajarwo, (2000), "Analisis Faktor-Faktor Yang Mempengaruhi Praktik Perataan Laba Pada Perusahaan yang Terdaftar di Berbagai Pasar Modal Utama ASEAN," Tesis Pascasarjana Universitas Gadjah Mada, Yogyakarta.

Zuhroh, D., (1996), "Faktor-Faktor yang Berpengaruh pad Tindakan Perataan Laba pada Perusahaan Go Publik di Indonesia," Tesis Pascasarjana Universitas Gadjah Mada, Yogyakarta. 


\section{Lampiran 1}

\section{Nama Perusahaan}

\begin{tabular}{|c|c|c|}
\hline NO. & KODE & NAMA PERUSAHAAN \\
\hline 1. & TMPI & Agis \\
\hline 2. & ALKA & Alasaka Industrindo \\
\hline 3. & ALMI & Alumindo Light Metal \\
\hline 4. & AKRA & Aneka Kimia Raya \\
\hline 5. & MYTX & Apac Citra Centertex \\
\hline 6. & AKPI & Argha Karya Prima Industri \\
\hline 7. & ARGO & Argo Pantes \\
\hline 8. & HPSB & Aryaduta Hotels \\
\hline 9. & ASIA & Asiana Multikreasi \\
\hline 10. & ASGR & Astra Graphia \\
\hline 11. & ASII & Astra International \\
\hline 12. & AUTO & Astra Otoparts \\
\hline 13. & BNBR & Bakrie\&Brothers \\
\hline 14. & BRPT & Barito Pasific Timber \\
\hline 15. & BYSB & Bayer Indonesia SB \\
\hline 16. & BAYU & Bayu Buana \\
\hline 17. & BRNA & Berlina \\
\hline 18. & BIPP & Bhuwanatala Indah Permai \\
\hline 19. & BMTR & Bimantara Citra \\
\hline 20. & BRAM & Branta Mulia \\
\hline 21. & BUDI & Budi Acid Jaya \\
\hline 22. & BKSL & Bukit Sentul \\
\hline 23. & CNTX & Centex \\
\hline 24. & CPIN & Charoen Pokpand Indonesia \\
\hline 25. & CKRA & Ciptojaya Kontrindoreksa \\
\hline 26. & CTRA & Ciputra Development \\
\hline 27. & CTRS & Ciputra Surya \\
\hline 28. & CTBN & Citra Tubindo \\
\hline 29. & CPPR & CP. Prima \\
\hline 30. & DNKS & Dankos Laboratories \\
\hline 31. & DVLA & Darya Varia Laboratories \\
\hline 32. & DSUC & Daya Sakti Unggul Corp. \\
\hline 33. & DILD & Dharmala Intiland \\
\hline 34. & DART & Duta Anggada Reality \\
\hline 35. & DPNS & Duta Pertiwi Nusantara \\
\hline 36. & DUTI & Duta Pertiwi \\
\hline 37. & DYNA & Dynaplast \\
\hline 38. & EKAD & Ekadharma Tape Industri \\
\hline 39. & EPMT & Enseval Putra Megatrading \\
\hline 40. & ERTX & Eratex Djaja Limited \\
\hline 41. & ETWA & Eterindo Wahanatama \\
\hline 42 & ESTI & Ever Shine Textile Industri \\
\hline 43 & FASW & Fajar Surya Wisesa \\
\hline 44 & |FAST & Fast Food Indonesia \\
\hline 45 & GJTL & Gajah Tunggal \\
\hline
\end{tabular}

\begin{tabular}{|c|c|c|}
\hline NO. & KODE & NAMA PERUSAHAAN \\
\hline 78. & KDSI & Kedaung Setia Industrial \\
\hline 79. & KIAS & Keramika Indonesia \\
\hline 80. & KOMI & Komatsu Indonesia \\
\hline 81. & KKGI & Kurnia Kapuas Utama \\
\hline 82. & LMPI & Langgeng Makmur Plastik I \\
\hline 83. & LTLS & Lautan luas \\
\hline 84. & LMSH & Lion Mesh Prima \\
\hline 85. & LION & Lion Metal Works \\
\hline 86. & LPCK & Lippo Cikarang \\
\hline 87. & LPKR & Lippo Karawaci \\
\hline 88. & LPLD & Lippo Land Development \\
\hline 89. & MAMI & Mas Murni Indonesia \\
\hline 90. & MPPA & Matahari Putra Prima \\
\hline 91. & MTSM & Metro SupermarketRealty \\
\hline 92. & MTDL & Metrodata Electronics \\
\hline 93. & MDRN & Modern Photo Film Company \\
\hline 94. & MDLN & Modernland Realty \\
\hline 95. & MLIA & Mulia Industrindo \\
\hline 96. & MLND & Mulialand \\
\hline 97. & MLPL & Multipolar \\
\hline 98. & MRAT & Mustika Ratu \\
\hline 99. & NIPS & Nipress \\
\hline 100. & PWON & Pakuwon Jati \\
\hline 101. & PBRX & Pan Brothers Tex \\
\hline 102. & PAFI & Panasia Filament Inti \\
\hline 103. & HDTX & Panasia Indosyntec \\
\hline 104. & PWSI & Panca Wiratama \\
\hline 105. & PICO & Pelangi Indah Canindo \\
\hline 106. & KONI & Perdana Bangun Pusaka \\
\hline 107. & PLIN & Plaza Indonesia Realty \\
\hline 108. & PRAS & Prima Alloy Steel \\
\hline 109. & BIMA & Primarindo Asia Infrastruktur \\
\hline 110. & PGIN & Procter\&Gambler Indonesia \\
\hline 111. & PNSE & Pudjiadi \& Sons Estate \\
\hline 112. & RALS & Ramayana Lestari Sentosa \\
\hline 113. & RICY & Ricky Putra Globalindo \\
\hline 114. & RBMS & Ristia Bintang Mahkota Sejati \\
\hline 115. & RDTX & Roda Vivatex \\
\hline 116. & SRSN & Sarana Nugraha \\
\hline 117. & SCPI & Schering Plough Indonesia \\
\hline 118. & SMSM & Selamat Sempurna \\
\hline 119. & SMCB & Semen Cibinong \\
\hline 120. & SMGR & Semen Gresik \\
\hline 121 & BATA & Sepatu Bata \\
\hline 122. & SIPD & Sierad Produce \\
\hline
\end{tabular}


46. GDYR Goodyear Indonesia

47. GRIV Great River International

48. KBLI GT Kabel Indonesia

49. ADMG GT Petrochem Industries

50. WYRX Hanson Industri Utama

51. HERO Hero Supermarket

52. HEXA Hexindo Adiperkasa

53. IGAR Igarjaya

54. INKP Indah Kiat Pulp Dan Paper

55. INAI Indal Aluminium Industry

56. INTP Indocement Tunggal Prakasa

57. INAF Indofarma

58. IMAS Indomobil Sukses Internatio

59. MORE Indonesia Prima Property

60. INDR Indorama Syntetic

61. INDS Indospring

62. $\mathrm{INCl}$ Intan Wijaya Iternasional

63. INTD Inter Delta

64. IKAI Intikeramik Alamasri Industri

65. INTA Intraco Penta

66. ITMA Itamaraya Gold Industri

67. JKSW Jakarta Kyoei Steel Work

68. JSPT Jakarta Setiabudi Internatio

69. JPFA Japfa

70. JPRS Jaya Pari Steel Corp.

71. JRPT Jaya Real Property

72. JECC Jembo Cable Company

73. KBLM Kabelindo Murni

74. KLBF Kalbe Farma

75. KARW Karwell Indonesia

76. KIJA Kawasan Industri Jababeka

77. $\mathrm{KICl}$ Kedaung Indah Can
123. SONA Sona Topas Tourism Industri

124. SOBI Sorini Corporation

125. SQBI Squibb Indonesia

126. SCCO Sucaco

127. SULI Sumalindo Lestari Jaya

128. IKBI Sumi Indo Kabel

129. SMRA Summarecon Agung

130. SSTM Sunson Textile manufacture

131. SPMA Suparma

132. SAIP Surabaya Agung Industry

133. SUDI Surya Dumai Industri

134. SHSA Surya Hidup Satwa

135. SSIA Surya Semesta Internusa

136. TOTO Surya Toto Indonesia

137. SIIP Surya inti Permata

138. SMDM Suryamas Dutamakmur

139. TBMS Tembaga Mulia Semanan

140. TSPC Tempo Scan Pacific

141. TEJA Texmaco Jaya

142. TPEN Texmaco Perkasa Enginering

143. TFCO Tifico

144. TGKA Tigaraksa Satria

145. TIRA Tira Austinite

146. TPIA Tri Polyta Indonesia

147. TRST Trias Sentosa

148. TURI Tunas Ridean

149. UNIC Unggul Indah cahaya

150. UNVR Unilever Indonesia

151. UNTR United Tractors

152. VOKS Voksel Electric

153. UGAR Wahana Jaya Perkasa 